195

Received: January 25, 2015

Accepted: May 10, 2015
In print: ISSN $1857-6907$

On line: ISSN $1857-7709$

UDC: 637.524.043:635.7

\title{
INFLUENCE OF THE BASIL EXTRACTS AND ARILLUS MYRISTICAE ON ANTIOXIDATIVE CHANGES IN SEMIDURABLE SAUSAGES
}

\author{
Aco Kuzelov ${ }^{1}$, Darko Andronikov ${ }^{2}$, Nako Taškov ${ }^{3}$, Dušica Saneva ${ }^{3}$, \\ Dijana Naseva ${ }^{1}$, Elenica Sofijanova ${ }^{4}$ \\ ${ }^{1}$ Faculty of Agriculture, University "Goce Delčev", Krste Misirkov bb, Štip, Republic of Macedonia \\ ${ }^{2}$ Faculty of Technology, University "Goce Delčev", Krste Misirkov bb, Štip, Republic of Macedonia \\ ${ }^{3}$ Faculty of Tourism and Business logistics University "Goce Delčev", \\ Krste Misirkov bb, Štip, Republic of Macedonia \\ ${ }^{4}$ Faculty of Economics, University "Goce Delčev", Krste Misirkov bb, Štip, Republic of Macedonia \\ aco.kuzelov@ugd.edu.mk
}

In this paper are given the test results of antioxidative effect of basil extract and extract of Arillus myristicae by examination of degree of acidity and peroxide number on lipid for semidurable national sausage. After manufacture sausage was vacuum and stored at temperature of $+4^{\circ} \mathrm{C}$. Degree of acidity and peroxide number were examined 1,10 , $20,30,40$ and 50 days of production. Best results give the sample with the addition of $0.3 \mathrm{~g}$ of basil extract per kg mixture compared with samples with Arillus myristicae extract.

Key words: basil extract; Arillus myristicae extract; degree of acidity; peroxide number; antioxidative effect

\section{ВЛИЈАНИЕ НА ЕКСТРАКТ ОД БОСИЛОК И ОД МУСКАТЕН ЦВЕТ ВРЗ АНТИОКСИДАТИВНИТЕ ПРОМЕНИ НА НАРОДЕН КОЛБАС}

\begin{abstract}
Во трудот се дадени резултатите од испитувањата на антиоксидативното дејство на екстракти од босилок и од мускатен цвет, преку испитување на параметрите киселински степен и пероксиден број, врз мастите на народен колбас. По производството колбасот беше вакуумиран и чуван на температура од $+4{ }^{\circ} \mathrm{C}$. Киселинскиот степен и пероксидниот број беа испитувани 1, 10, 20, 30, 40 и 50 дена по производството. Најдобри резултати даде пробата со додаток на 0.3 грама екстракт од босилок на килограм смеса во споредба со пробите со екстракт од мускатен цвет.
\end{abstract}

Клучни зборови: екстракт од босилок; екстракт од мускатен цвет, киселински степен; пероксиден број; антиоксидативно дејство

\section{INTRODUCTION}

The most common form of chemical deterioration is the oxidation of lipids in meat and meat products, with which comes to a reduction in their quality and changes in taste and smell (Kanner, 1994, Aguirrezábal et al., 2000). Oxidation of meat products may be reduced or inhibited using antioxidants and that way can be improved their quality and shelf-life (Yin and Cheng, 2003). In recent years, increased research for natural antioxidants because there are many negative effects of synthetic antioxidants (BHA, BHT and tertiary butyl hydroquinone (TBHQ) (Pokorný, 1991; Arihara, 2006). Recently, research are singleminded to the identification of antioxidants from sources of plants.

Here are given extracts of spices which contain biologically active compounds with antioxidative effect. In basil and basil extract key ingredients are chavicol, linalool and eugenol (Savić and Danon, 1985; Dragoev, 2004; Mondello et al., 2007; Leal et al., 2008). In Arillus myristicae and Arillus myristicae extract are eumicin, eugenol, safrol, izoeugenol, terpenes and alcohol (Savić and Danon, 1985). Some authors say that antioxi- 
dant effect have basil, Arillus myristicae and their extracts (Savić and Danon, 1985; Nguefack et al., 2004; Nebedum, et al., 2009; Sanchez et al., 2010). Because there is very little literature on the impact of data extracts basil and Arillus myristicae on the quality and durability of semidurable sausage, the aim of our study was to examine the effect of different concentrations of the extract of basil and extract of Arillus myristicae on the oxidative changes on semidurable national sausage.

\section{MATERIAL AND METHOD}

As material for examination we have used the semidurable sausage of the type produced home - national sausage. Sausage was produced in compliance with all veterinary sanitary regulations which apply in the Republic of Macedonia. For the production of the sausage the following raw material was used: beef second category $(25 \%)$, pork second category $(20 \%)$, fat tissue $(30 \%)$, meat steak $(10 \%)$ and hard water-ice $(15 \%)$. Per $1 \mathrm{~kg}$ is added: 18 grams of nitrite curing salt and 3 grams phosphate product, emulsifier $0.020 \mathrm{~g}$, spices mixture semidurable national sausage $0.040 \mathrm{~g}$ (Koleks Ljubljana, Slovenia). The mixture is stuffed into small pork's intestine. For the experiment four samples were prepared.

At first, samples were prepared with adding extract of basil:

Sample 1 - control sample without adding extract of basil.

Sample 2 - sample by adding $0.1 \mathrm{~g}$ of basil extract per $\mathrm{kg}$ mixture.

Sample 3 - sample by adding $0.2 \mathrm{~g}$ extract of basil per $\mathrm{kg}$ mixture.

Sample 4 - sample by adding $0.3 \mathrm{~g}$ extract of basil per $\mathrm{kg}$ mixture.

After prepared samples with adding extract of basil and full examination of samples were prepared samples with adding extract of Arillus myristicae:

Sample 1 - control sample without adding extract of Arillus myristicae.

Sample 2 - sample by adding $0.1 \mathrm{~g}$ extract of Arillus myristicae per kg.mixture.

Sample 3 - sample by adding $0.2 \mathrm{~g}$ extract of Arillus myristicae per $\mathrm{kg}$ mixture.

Sample 4 - sample by adding $0.3 \mathrm{~g}$ extract of Arillus myristicae per kg mixture.
The extracts of basil and garlic are produced in the company of ECOL Canada. Extracts were $100 \%$ pure, their microbiological picture was spotlessly and they were applied in production grinding the mixture. After filling and leaving the water to come out of the sausage, it was thermically prepared. Thermal processing is implemented by the following formula: 35 minutes drying, 20 minutes smoked at $62^{\circ} \mathrm{C}, 35$ minutes of boiling at $78^{\circ} \mathrm{C}$ or until the center of the product does not reach a temperature of $69-72^{\circ} \mathrm{C}$. After thermal processing, it was vacuumed with vacuum machine Vebomak. After vacuum packaging, sausage was stored in a chamber at a temperature of $+4^{\circ} \mathrm{C}$.

During storage on the $1^{\text {st }}, 10^{\text {th }}, 20^{\text {th }}, 30^{\text {th }}, 40^{\text {th }}$ and $50^{\text {th }}$ day of production, sausages were examined for degree of acidity and peroxide number.

Degree of acidity was examined by the method of ISO 660 (2000), peroxide number by ISO 3960 (2001). Each parameter is determined by three repetitions and the results are presented as mean value $\pm \mathrm{SD}$. The obtained results were processed by mathematical statistical method Microsoft Exel 1997-2003.

\section{RESULTS AND DISCUSSION}

The results of hydrolytic and oxidative changes in all four groups studied samples are shown in charts 1,2, 3 and 4.

The charts show that during storing sausages, the acid number (quantity of free fat) is increasing in all tested sausages, especially in the control group. In samples with adding of basil extract, peroxide number in the control is $0.70 \mathrm{mmol} / \mathrm{kg} \pm$ SD 0.02 and in the sample with the addition of 0.3 $\mathrm{g}$ extract per $\mathrm{kg}$ mixture is $0.48 \mathrm{mmol} / \mathrm{kg} \pm \mathrm{SD}$ 0.05. In samples with adding of Arillus myristicae extract, peroxide number in the control is 0.81 $\mathrm{mmol} / \mathrm{kg} \pm \mathrm{SD} 0.05$ and in the sample with the addition of $0.3 \mathrm{~g}$ extract per $\mathrm{kg}$ mixture is 0.49 $\mathrm{mmol} / \mathrm{kg} \pm \mathrm{SD} 0.05$. During storage the temperature of the sausages $+4^{\circ} \mathrm{C}$ in the samples with addition of basil and Arillus myristicae extract, peroxide number is constantly increasing. In samples with basil extract and Arillus myristicae extract, the peroxide number in the control samples is $(1.50 \mathrm{mmol} / \mathrm{kg} \pm \mathrm{SD} 0.2$ and $1.53 \mathrm{mmol} / \mathrm{kg} \pm \mathrm{SD}$ $0.5)$ and reducing in samples $3(0.69 \mathrm{mmol} / \mathrm{kg} \pm$ $\mathrm{SD} 0.02$ and $1.17 \mathrm{mmol} / \mathrm{kg} \pm \mathrm{SD} 0.4$ ). 
8

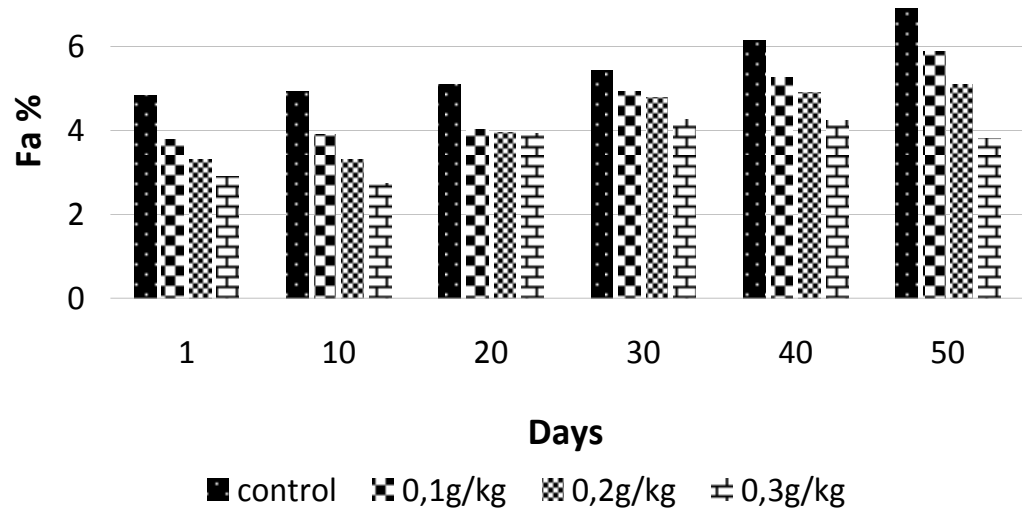

Chart 1. Changes in the degree of acidity in the four samples of tested sausages treated with basil extract during vacuum storage

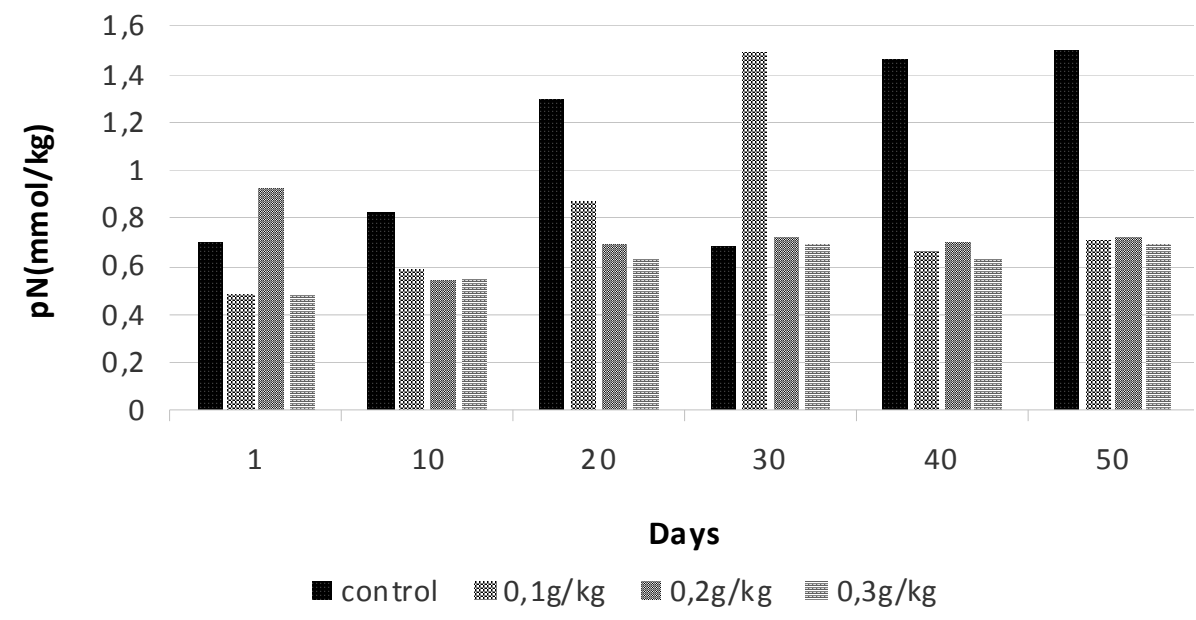

Chart 2. Changes of peroxide number in the four samples of tested sausages treated with basil extract during vacuum storage

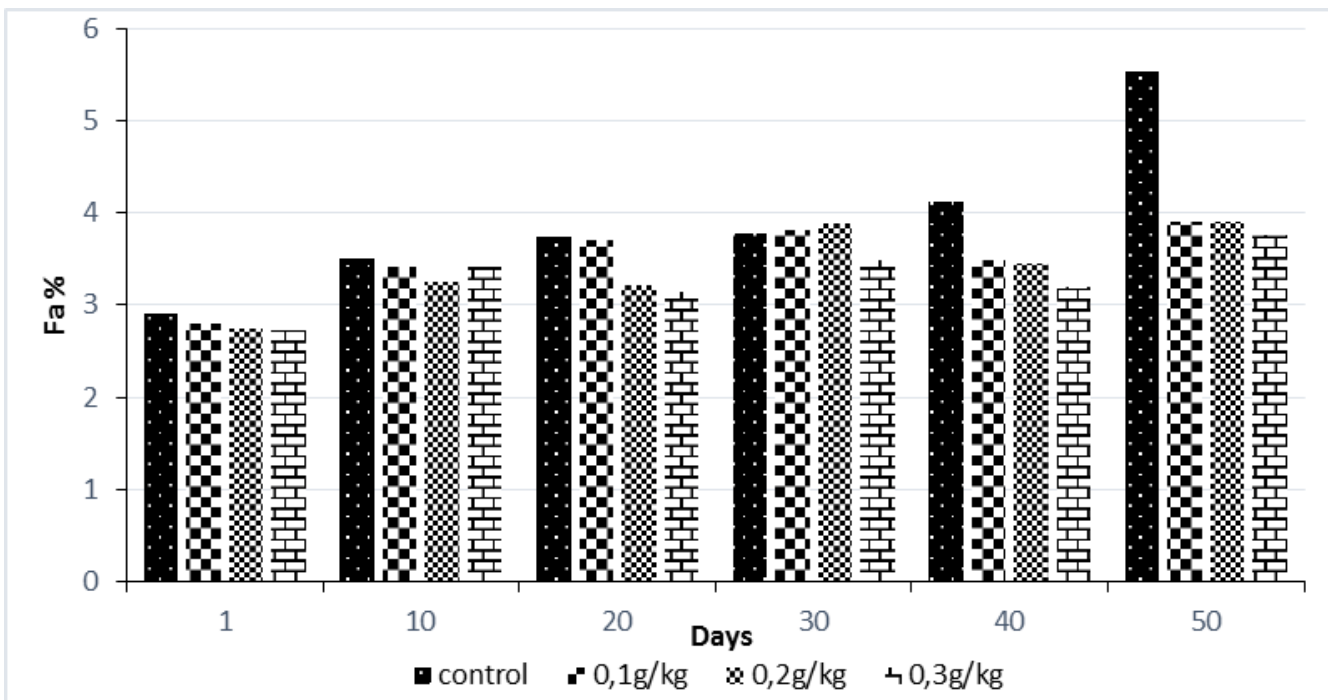

Chart 3. Changes in the degree of acidity in the four samples of tested sausages treated with Arillus myristicae extract during vacuum storage 


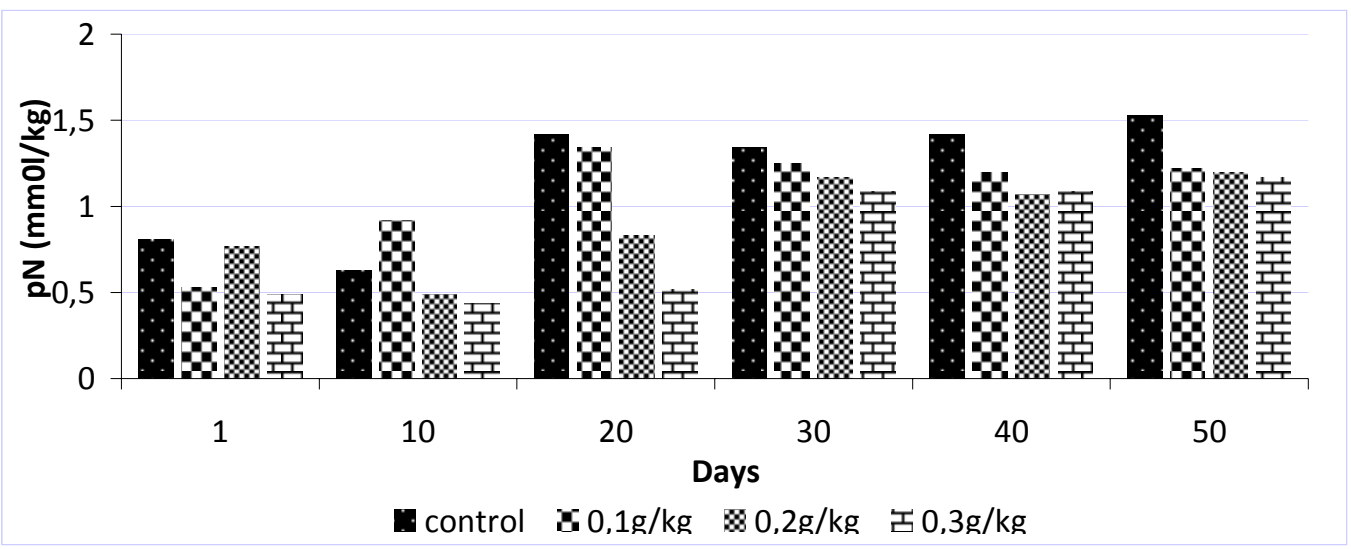

Chart 4. Changes of peroxide number in the four samples of tested sausages treated with Arillus myristicae extract during in vacuum storage

According Ostrić-Matijašević B. (1963) sensory changes of sausages are visible even when the value of the peroxide number is greater than 5 $\mathrm{mmol} / \mathrm{kg}$. It can be concluded that the process of oxidation in the tested samples is not expressed. Pičurić-Jovanivić et al. (2000) have examined the antioxidative activity of basil and basil extract and found that the extract of basil shows relatively little antioxidative effect.

The results that we have obtained are probably as a result of antioxidative effect of extracts of basil and Arillus myristicae or any their own ingredients and vacuum packaging sausages.

\section{CONCLUSIONS}

According to the above written, we can conclude the following: The best results of antioxidative properties have in sample 3 with $0.3 \mathrm{~g} / \mathrm{kg}$ extract of basil compared with Arillus myristicae extract. The extract of basil has something better antioxidative properties compared to Arillus myristicae extract.

\section{REFERENCES}

[1] Aguirrezábal, M. M., Mateo, J., Domínguez, M. C., Zumalacárregui, J. M.: The effect of paprika, garlic and salt on rancidity in dry sausages, Meat Science, 54, pp. 7781 (2000).

[2] Dragoev, S: Development of technology in meat and fish industry, Academic Publishing, UFT Plovdiv, pp. 96112 (2004).

[3] Kanner, J.: Oxidative processes in meat and meat products quality implications, Meat Science, 36, pp. 169-174 (1995).
[4] Leal, P. F., Maia, N. B., Carmello, Q. A. C., Catharino, R. R., Eberlin, M. N., Meireles, M. A. A.: Sweet basil (Ocimum basilicum) extracts obtained by supercritical fluid extraction (SFE): Global yields, chemical composition, antioxidant activity, and estimation of the cost of manufacturing, Food and Bioprocess Tech., 1 (4), pp. 326-338 (2008).

[5] Mondello, L., Zappia, G., Cotroneo, A., Bonaccorsi, I., Chowdhury, J. U., Yusufi, M., Dugo, G.: Studies on the essential oil-bearing plants of Bangladesh. Part VIII. Composition of some Ocimum oils O. basilicum L. var. purpurascens; $O$. sanctum L. green; $O$. sanctum L. purple; $O$. americum L. citral type; $O$. americanum L. camphor type, Flavour Fragr J., 17, pp. 335-340 (2007).

[6] Nguefack, J., Budde, B. B., Jakobsen M.: Five essential oils from aromatic plants of Cameroon: Their antibacterial acitivity and ability permeabilize the citoplazmic membrane Listeria innocua examined by flow cytometry letters in Applied Microbiology, Res. J. of Medicinal Plant, 39 (5), pp. 395-400 (2004).

[7] Nebedum, J., Ajeigbe K. O., Nwobodo, E., Uba, C., Adesanya, O., Fadera, O., Ofusori, D.: Comparative study of the ethanolic extracts of four Nigerian plants against some pathogenic microorganisms, Res. J. of Medicinal Plant, 3 (1), pp. 23-28 (2009).

[8] Ostrić-Matijašević, Biserka: Relationships between the results of an objective method and organoleptic changes fat meats, Technology, 1, pp. 5-6 (1963).

[9] Pičurić Jovanović K., Milovanović, M., Rabrenović, B.: Relative antioxidant of basil (Ocimonum basilicum L.), Acta periodica Technologica, 31, pp. 201-206 (2000).

[10] Savić, I., Danon, J.: Spices of the Meat Processing, Veterinary Faculty in Belgrade, pp. 25-27 (1982).

[11] Sanchez Eduardo, Santos Garcia, Heredia Norma: Extract of edible and medicinal plants damage membranes of Vibrio cholerae, Applied and environmental Microbiology, 76 (20) pp. 6888-6894 (October, 2010), doi: 10.1128/AEM.03052-09.

[12] Yin, M. C., Cheng, W S.: Antioxidant and antimicrobial effects of four garlic-derived organic sulfur compounds in ground beef, Meat Science, 63, pp. 23-28 (2003). 